\title{
Mannan-binding lectin regulates dendritic cell maturation and cytokine production induced by lipopolysaccharide
}

\author{
Mingyong Wang ${ }^{1,2}$, Yani Zhang ${ }^{1}$, Yue Chen ${ }^{1}$, Liyun Zhang ${ }^{1}$, Xiao Lu', Zhengliang Chen ${ }^{1 *}$
}

\begin{abstract}
Background: Mannan-binding lectin (MBL) is a pattern-recognition molecule present in serum, which is involved in the innate immune defense by activating complement and promoting opsonophagocytosis. Dendritic cells (DCs) are professional antigen presenting cells (APCS) that are crucial for the initiation of adaptive immunity. Lipopolysaccharide (LPS) has been shown to be a strong activator of the inflammatory response and immune regulation. We first examined whether MBL modulated LPS-induced cellular responses, then investigated possible mechanisms of its inhibitory effect.

Results: MBL at higher concentrations $(10-20 \mu \mathrm{g} / \mathrm{ml})$ significantly attenuated LPS-induced maturation of monocytederived DCs (MDCs) and production of proinflammatory cytokines (e.g., IL-12 and TNF- $\alpha$ ), and inhibited their ability to activate allogeneic T lymphocytes. It bound to immature MDCs at physiological calcium concentrations, and was optimal at supraphysiological calcium concentrations. MBL also bound directly to immature MDCs and attenuated the binding of LPS to the cell surfaces, resulting in decreased LPS-induced nuclear factor- $\kappa$ B (NF- $\kappa \mathrm{B})$ activity in these cells.

Conclusion: All these data suggest that MBL could affect the functions of DCs by modifying LPS-induced cellular responses. This study supports an important role for MBL in the regulation of adaptive immune responses and inflammatory responses.
\end{abstract}

\section{Background}

Mannan-binding lectin (MBL), a member of the collectin family in the C-type lectin superfamily, is a multimeric protein containing collagen-like sequences. It is synthesized and secreted into the blood by hepatocytes. It has the overall 'bundle-of-tulips' structure first described for C1q [1]. The MBL polypeptide comprises four domains: a cysteine-rich $\mathrm{N}$-terminal domain, a collagen-like region (CLR) that contains Gly-X-Y repeats (where $\mathrm{X}$ is any amino acid and $\mathrm{Y}$ is often hydroxyproline or hydroxylysine), a neck region and a C-terminal carbohydrate-recognition domain (CRD) [2-7]. The MBL polymer is composed of as many as six homogenous subunits [8], but only the more highly polymeric forms have biological activity and can fix complement.

\footnotetext{
* Correspondence: zhlchen@fimmu.com

'Department of Immunology, Southern Medical University, Guangzhou, 510515, PR China

Full list of author information is available at the end of the article
}

Dendritic cells (DCs) are highly efficient antigen-presenting cells that play a central role in orchestrating adaptive immune responses to pathogens [9]. In their immature form (imDCs), they can capture antigen very efficiently by macropinocytosis, endocytosis [10], and phagocytosis [11] through different cell surface molecules, e.g. mannose receptor, Toll-like receptors (TLRs) or scavenger receptors. To elicit an immune response, DCs must undergo a maturation process, which is initiated by inflammatory signals and is completed after contact with T cells. Maturation enables DCs to migrate from peripheral tissues to lymphoid organs and to acquire a very potent antigen-presenting capacity. Mature DCs are also the initial and most prominent source of the cytokines that govern the development of Th1 responses (e.g., IL-12). DC maturation is known to be induced by several stimuli, including bacterial components [e.g., lipopolysaccharide (LPS)], heat shock
C Biomed Central

() 2011 Wang et al; licensee BioMed Central Ltd. This is an Open Access article distributed under the terms of the Creative Commons Attribution License (http://creativecommons.org/licenses/by/2.0), which permits unrestricted use, distribution, and reproduction in any medium, provided the original work is properly cited. 
proteins, viral products (e.g., dsRNA) and endogenous factors such as inflammatory cytokines [12].

It has been reported that other members of the soluble defensive collagen family such as surfactant protein A (SP-A), surfactant protein D (SP-D) and complement $\mathrm{C} 1 \mathrm{q}$, have roles in immune regulation by interacting with various cells. For instance, SP-A inhibits the differentiation and maturation of DCs [13] and modulates cellular responses induced by LPS through interacting with CD14 [14]; SP-A suppresses TNF- $\alpha$ secretion from alveolar macrophages stimulated by LPS [15], and SP-Adeficient mice produce significantly more TNF- $\alpha$ than wild-type mice after intratracheal LPS administration [16]. SP-D enhances bacterial antigen presentation by bone marrow-derived DCs [17]. C1q regulates LPSinduced cytokine production in bone marrow-derived DCs [18] and induces maturation of human DCs [19].

As a key soluble pattern recognition molecule in the innate immune system, MBL has been reported to influence the cytokine network after stimulation by various microorganisms [20-23]. To date, however, little knowledge has been obtained about its role in the regulation of adaptive response. Since DCs play key roles in initiating adaptive responses, it will be useful to know whether and how this member of the collectin family regulates LPS-induced biological functions and the possible mechanisms in DCs.

\section{Results}

\section{Purification of MBL}

MBL was purified from pooled human plasma samples containing high concentrations (approximately $2500 \mu \mathrm{g}$ $\mathrm{MBL} / \mathrm{L}$ on average). SDS-PAGE and western blotting showed that the highly purified MBL was a functional multimer composed of 32KD peptide chains (Figure 1). It was highly bioactive, as demonstrated by a ligandbinding assay and yeast coagulation (data not shown).

\section{MBL suppresses LPS-induced MDC maturation}

It is well known that DC maturation is induced by LPS. During DC maturation, the expression of receptors required for phagocytosis is down-regulated, whereas MHCII and co-stimulatory molecules such as CD80 and CD86 are up-regulated [24]. To investigate whether MBL influences DC maturation, imMDCs were stimulated with smooth LPS $(100 \mathrm{ng} / \mathrm{ml})$ in the presence of increasing concentrations of $\mathrm{MBL}(0,1,10,20 \mu \mathrm{g} / \mathrm{ml})$ for 2 days. Cell maturation was assessed by flow cytometry (FCM). As shown in Figure 2, LPS induced elevated expression of CD83, CD86, and MHC II, but these effects were strongly inhibited by MBL at higher concentrations $(10-20 \mu \mathrm{g} / \mathrm{ml})$ compared with the corresponding cells without MBL treatment $(P<0.05)$; HSA $(20 \mu \mathrm{g} / \mathrm{ml})$ and lower MBL concentrations $(1 \mu \mathrm{g} / \mathrm{ml})$

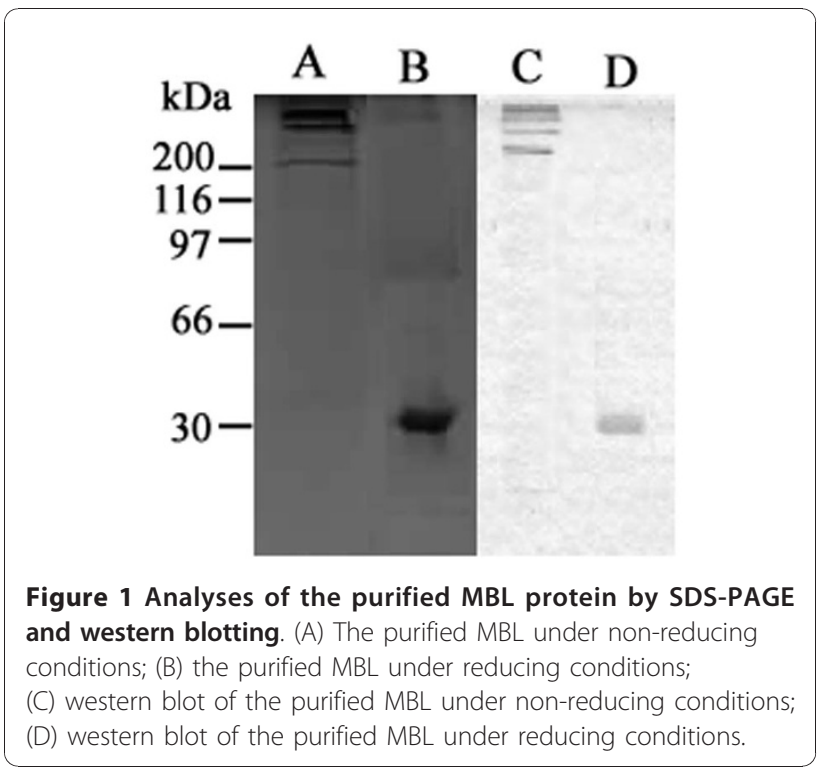

had no such effect. Inclusion of anti-MBL polyclonal antibody (pAb) during the preincubation of the cells with MBL restored the expression of CD83, CD86, and MHC II on DCs (Figure 2), indicating that MBL specifically inhibited the interaction between LPS and imMDCs.

\section{MBL inhibits TNF- $\alpha$ and IL-12 p40+p70 production from LPS-stimulated MDCs}

ImMDCs were stimulated with LPS and exhibited maximal response to secreted proinflammatory cytokines such as IL-12 and TNF- $\alpha$ (data not shown). Cytokines produced by MDCs are known to be important in regulating the adaptive immune response, directing it to either the Th1 or the Th2 pathway. To investigate whether MBL affects cytokine production by MDCs stimulated with LPS, imMDCs were stimulated with LPS $(100 \mathrm{ng} / \mathrm{ml})$ in the presence of increasing concentrations of $\operatorname{MBL}(0,1,10,20 \mu \mathrm{g} / \mathrm{ml})$ for $24 \mathrm{~h}$, and the supernatants were analyzed by ELISA. As shown in Figure 3, the inductions of TNF $-\alpha$ and IL- 12 p $40+$ p70 by LPS were strongly inhibited by MBL at higher concentrations (10-20 $\mu \mathrm{g} / \mathrm{ml})$, compared with the corresponding imMDCs without MBL treatment $(P<0.05)$, but HSA $(20 \mu \mathrm{g} / \mathrm{ml})$ and lower $\mathrm{MBL}$ concentrations $(1 \mu \mathrm{g} / \mathrm{ml})$ had no such effect. Inclusion of Anti-MBL pAb during the preincubation of the cells with MBL restored the secretion of TNF- $\alpha$ and IL-12 p40+p70 (Figure 3), indicating that the inhibitory effect of MBL is specific.

\section{MBL attenuates allogeneic $T$ cell proliferation induced by LPS-stimulated MDCs}

As mature DCs are known to be the most potent $\mathrm{T}$ cell activators, we next tested whether MBL affects the 


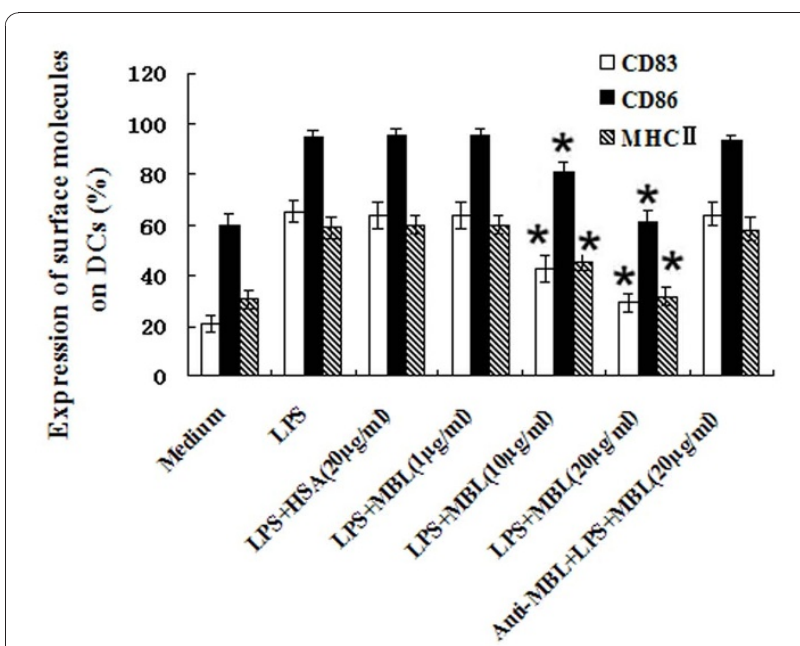

Figure $2 \mathrm{MBL}$ suppresses LPS-induced MDC maturation. ImMDCs were stimulated with LPS $(100 \mathrm{ng} / \mathrm{ml})$ in the presence of the indicated concentrations of $\mathrm{HSA}, \mathrm{MBL}$, or MBL and anti-MBL pAb for 2 days. Cell maturation was assessed by flow cytometry. ${ }^{*} P<0.05$ as compared to LPS-stimulated group. Similar results were observed in three independent experiments.

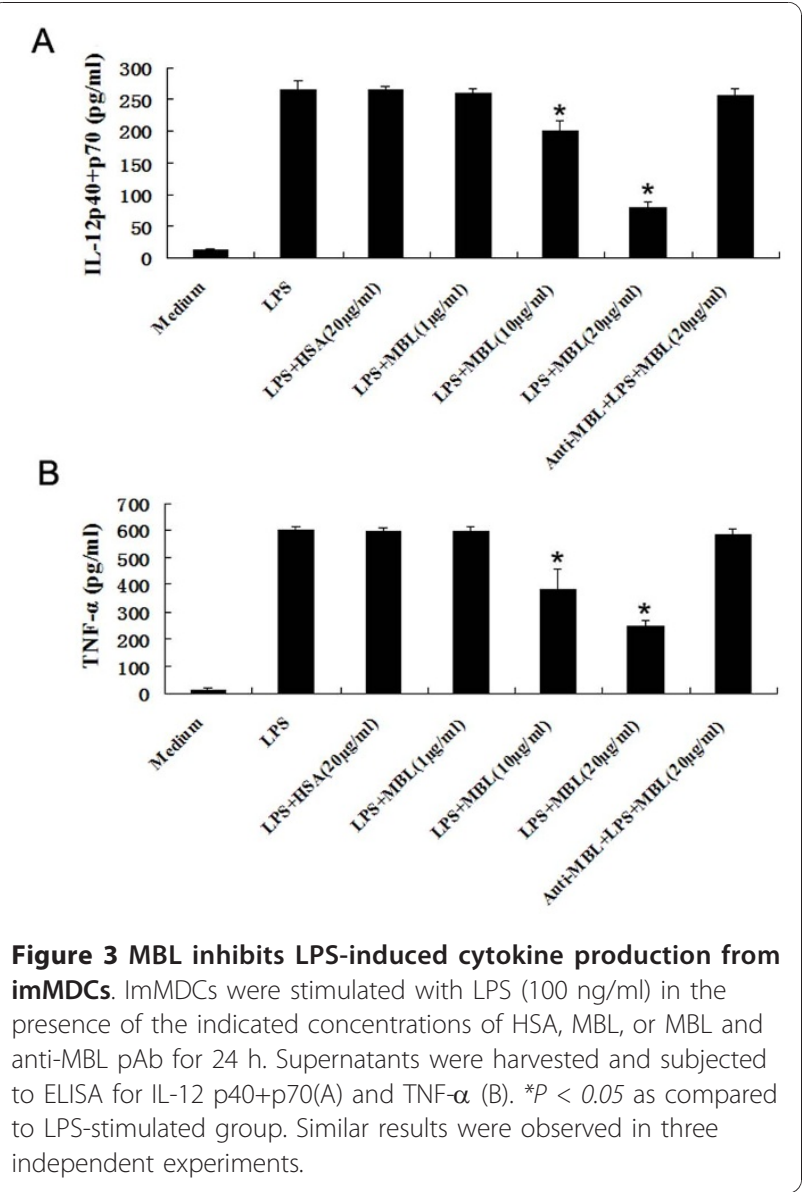

proliferative response of allogeneic $\mathrm{T}$ cells induced by LPS-stimulated MDCs. As demonstrated in Figure 4, $\mathrm{T}$ lymphocytes induced by LPS-stimulated MDCs cocultured with MBL $(15 \mu \mathrm{g} / \mathrm{ml})$ showed significantly lower proliferation than the corresponding MDCs without MBL treatment $(P<0.05)$; HSA $(15 \mu \mathrm{g} / \mathrm{ml})$ had no effect. In control samples, MDCs incubated in medium only or primed with LPS were used for the mixed lymphocyte reaction. Inclusion of anti-MBL pAb during the preincubation of the cells with MBL restored allogeneic $\mathrm{T}$ cell proliferation (Figure 4), further indicating the specific inhibitory effect of MBL.

\section{MBL attenuates the binding of LPS to imMDCs}

We next examined whether MBL altered LPS binding to imMDCs. When the cells were incubated at $4{ }^{\circ} \mathrm{C}$ with labeled smooth LPS (Figure 5A), significant LPS binding was observed on the cell surface (Figure 5A, dotted line). After the cells were preincubated with MBL $(10 \mu \mathrm{g} / \mathrm{ml})$, this cell-surface binding of the labeled smooth LPS was significantly attenuated (Figure 5A, black solid line). Inclusion of anti-MBL pAb during the preincubation of the cells with MBL restored the binding of smooth LPS to the cell surface (Figure 5B), indicating that MBL specifically inhibits the interaction between smooth LPS and the imMDCs.

We also checked whether MBL itself can bind to the LPS used in present experiments. The results showed that MBL bound to rough LPS from E. coli O111: B4

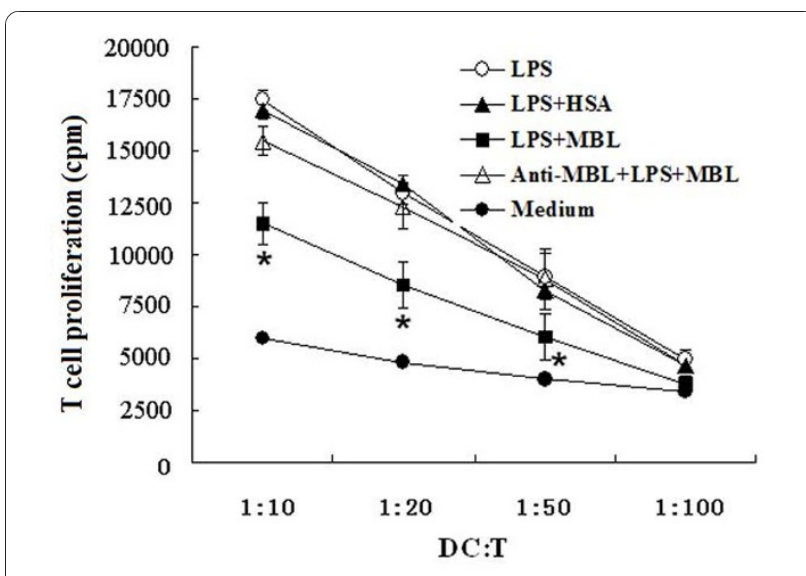

Figure $4 \mathrm{MBL}$ attenuates allogeneic $\mathrm{T}$ cell proliferation induced by LPS-primed MDCs. T cells obtained from PBMC $\left(2 \times 10^{5}\right.$ cells/ well) were co-cultured with either imMDCs, MBL-preincubated and LPS-primed MDCs, HSA-preincubated and LPS-primed MDCs, or LPS-primed MDCs at the indicated DC:T cell ratios. Anti-MBL PAb was used to demonstrate the specificity of the MBL-induced response. Proliferation of T cells was determined after 4 days of culture by ${ }^{3} \mathrm{H}$-thymidine uptake. Data given as mean \pm S.D. of triplicate samples are representative of four independent experiments. ${ }^{*} P<0.05$ as compared to LPS-stimulated group. 

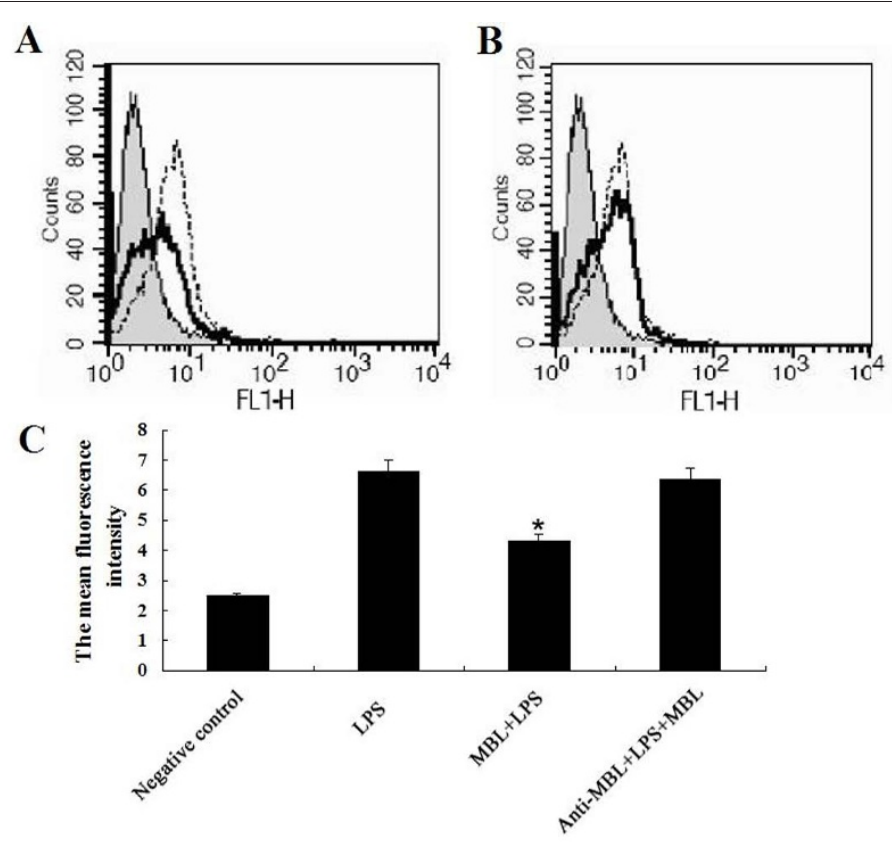

Figure $5 \mathrm{MBL}$ attenuates the binding of smooth LPS to imMDCs. ImMDCs were preincubated with (black solid line) or without (dotted line) MBL $(10 \mu \mathrm{g} / \mathrm{ml})$ for $30 \mathrm{~min}(\mathrm{~A})$, or with anti-MBL pAb (30 $\mathrm{\mu g} / \mathrm{ml})$ and MBL (black solid line) for $30 \mathrm{~min}(\mathrm{~B})$, and further incubated at $4^{\circ} \mathrm{C}$ for 30 min with Alexa488-labeled smooth LPS (E. coli O111: B4). The binding of LPS on the cell surface was determined by FACScan. The histograms shown are representatives from three experiments. Shaded curves, the negative control without labeled LPS. (C) Mean fluorescence intensity, data given as mean \pm S.D. from three independent experiments. ${ }^{*} P<0.05$ as compared to LPS group.

mutant (J5) but not to smooth LPS from E. coli O111: B4 (Additional file 1, Fig. S1), suggesting that the MBLimMDCs interaction rather than an MBL-LPS interaction affects the LPS-induced cellular responses.

\section{$\mathrm{Ca}^{2+}$-dependent binding of MBL to imMDCs}

When imMDCs were incubated with biotinylated MBL at physiological calcium concentrations (buffer A), there was definite but slight MBL binding to the cells, as demonstrated by FCM (Figure 6A). At higher $\mathrm{Ca}^{2+}$ concentrations the binding was markedly increased (Figure $6 \mathrm{~B}, \mathrm{C})$; also, the binding was markedly reduced in the absence of $\mathrm{Ca}^{2+}$ (Figure 6D). These results showed that MBL interacted with imMDCs in a $\mathrm{Ca}^{2+}$-dependent manner.

\section{MBL inhibits NF- $\kappa$ B DNA-binding and translocation in imMDCs}

The next question is whether MBL modulates LPSinduced signaling as a consequence of its interaction with surface molecules on imMDCs. Therefore, we investigated the effects of MBL on LPS-induced NF- $\kappa$ B activation in imMDCs, using two methods: electrophoretic mobility shift assay (EMSA) and western blotting. For EMSA, when nuclear extracts from LPS-stimulated imMDCs were incubated with $\mathrm{p} 40 \mathrm{NF}-\kappa \mathrm{B}$ probe, NF- $\kappa \mathrm{B}$ binding was enhanced within $1 \mathrm{~h}$ after LPS-stimulation, and MBL $(15 \mu \mathrm{g} / \mathrm{ml})$ reduced the DNA binding activity; DNA binding was restored by including anti-MBL pAb (Figure 7A). This binding of the complex was specific because it could be competed away with a 100-fold molar excess of unlabeled consensus NF- $\kappa$ B oligonucleotide (data not shown). For western blotting, analysis of corresponding nuclear fractions using anti-p65 Ab confirmed that LPS significantly increased NF- $\kappa \mathrm{B}$ translocation from the cytoplasm to the nucleus in imMDCs, and treatment with $15 \mu \mathrm{g} / \mathrm{ml} \mathrm{MBL}$ strongly inhibited this effect (Figure $7 \mathrm{~B}$ ). Inclusion of anti-MBL pAb restored NF- $\kappa \mathrm{B}$ translocation from the cytoplasm to the nucleus (Figure $7 \mathrm{~B})$, further indicating the specific inhibitory effect of MBL on the interaction between smooth LPS and the imMDCs.

\section{Discussion}

This study demonstrates a new biological function of MBL in regulating LPS-induced MDCs maturation and cytokine production. MBL bound to imMDCs at physiological calcium concentrations, but binding was optimal at supraphysiological concentrations. Furthermore, direct binding of MBL to imMDCs attenuated the binding of LPS to the cell surface and decreased LPS-induced NF- $\kappa$ B activity, suggesting that it affected MDC functions by modifying the LPS-induced cellular responses. 

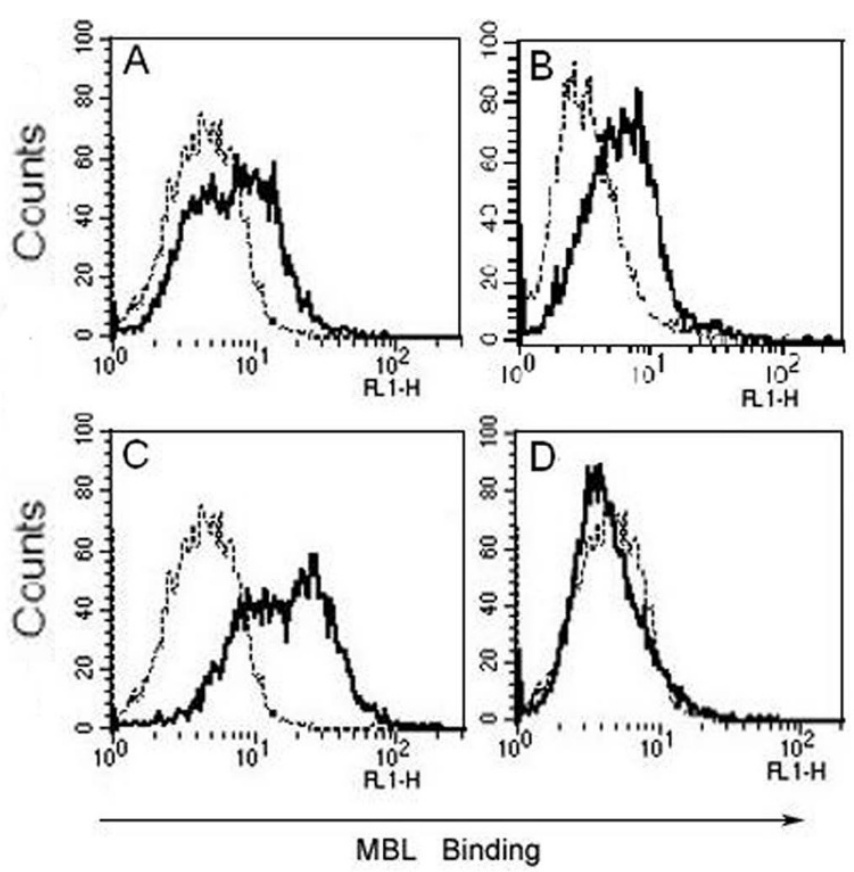

Figure $6 \mathrm{Ca}^{2+}$-dependent binding of MBL to imMDCs. (A) Tris-buffered saline with $1.5 \mathrm{mM} \mathrm{CaCl}_{2}$; (B) Tris-buffered saline with $5 \mathrm{mM}$ CaCl 2 ; (C) Tris-buffered saline with $10 \mathrm{mM} \mathrm{CaCl}$; (D) Tris-buffered saline with $5 \mathrm{mM}$ EDTA. Each solution of imMDCs was added with the biotinylated MBL $(10 \mu \mathrm{g} / \mathrm{ml})$ for $10 \mathrm{~min}$ incubation before addition of ExtrAvidin-FITC. After incubation for $30 \mathrm{~min}$ on ice, binding of MBL to the cells was analyzed by FACScan, as shown in the representative histograms (A-D). Black lines, biotinylated MBL binding; dotted lines, negative controls (the cells only). These data are representative of four independent experiments.

DCs are professional APCs that are crucial in the initiation of adaptive immunity [12]. They recognize pathogens through pattern recognition receptors (PRRs) that are triggered by pathogen-associated molecular patterns, leading to DC maturation. Maturation is a key process in DC biology and determines whether an immune response or tolerance will be initiated upon interaction with a given antigen. It is well accepted that imDCs induce $\mathrm{T}$ cell tolerance by inducing regulatory $\mathrm{T}$ cells [25]. To determine whether MBL affects LPSinduced MDC maturation, imMDCs were cultivated with MBL at a range of final concentrations from 0 to $20 \mu \mathrm{g} / \mathrm{ml}$. The results showed that cells treated with high MBL concentrations (10-20 $\mu \mathrm{g} / \mathrm{ml})$ expressed significantly less CD83, CD86, and MHC II than the corresponding MDCs stimulated with LPS only. In addition, the proliferation of allogeneic $\mathrm{T}$ lymphocytes induced by LPS-treated MDCs was significantly inhibited when they were co-cultured with $15 \mu \mathrm{g} / \mathrm{ml} \mathrm{MBL}$, suggesting that MBL could regulate adaptive immune systems by modulating DC maturation.

Recently Macdonald et al. [26] reported that rhMBL did not directly influence DC differentiation or maturation. Mature DCs, prepared in the presence of rhMBL

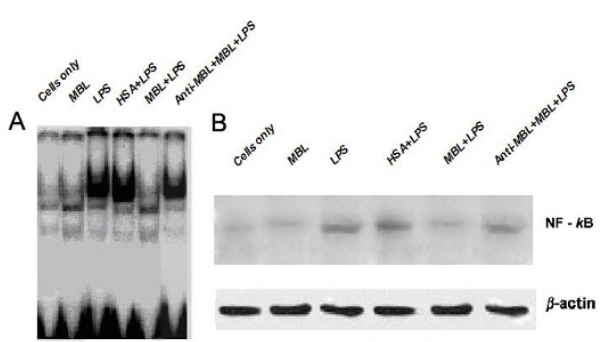

Figure $7 \mathrm{MBL}$ decreases LPS-stimulated NF- $\kappa$ B binding activity and translocation in imMDCs. (A) LPS-induced DNA-binding activity of NF- $\kappa$ B is inhibited by MBL. ImMDCs $\left(5 \times 10^{5}\right.$ cells/sample) were stimulated with LPS $(100 \mathrm{ng} / \mathrm{ml})$ in the presence of $15 \mu \mathrm{g} / \mathrm{ml}$ of $H S A$, anti-MBL PAb and MBL, or MBL for $1 \mathrm{~h}$, then harvested to prepare nuclear extracts. The nuclear extracts were mixed with radiolabeled NF- $\kappa$ B oligonucleotide probe and analyzed with EMSA. (B) MBL inhibits NF- $\kappa$ B translocation in imMDCs. ImMDCs $\left(5 \times 10^{5}\right.$ cells/sample) were stimulated with LPS $(100 \mathrm{ng} / \mathrm{ml})$ in the presence of $15 \mu \mathrm{g} / \mathrm{ml} \mathrm{HSA}$, anti-MBL PAb and MBL, or MBL for $1 \mathrm{~h}$, then the cells were harvested to prepare nuclear extracts. The proteins in the nuclei-free supernatants were separated by $10 \%$ SDS-PAGE, followed by transfer to a nitrocellulose membrane. After blocking, the membrane was incubated with the NF- $\kappa \mathrm{B}$-specific mouse antihuman mAb p65, followed by HRP-conjugated secondary antibody. $E C L$ was used to visualize the protein bands. As an internal control, actin was used. 
and subsequently co-cultured with allogeneic mononuclear cells, markedly promoted the production of IL-1, IL- 6 and TNF- $\alpha$ in vitro. This influence required the presence of rhMBL during DC maturation and was critically dependent on the presence of monocytes. However, the data presented in this study demonstrate that MBL suppresses DC maturation and cytokine secretion in the presence of LPS in vitro, suggesting that MBL may act differently under different (physiological or pathological) conditions and shows much versatility in regulating cellular immunity in addition to its established role as an opsonin.

It has been recognized that the nature of the innate immune response significantly influences the nature of the subsequent adaptive immune response. Both soluble and membrane-bound PRRs of the innate immune system assess the level of danger of a particular intrusion and initiate a program of protection for the host [27]. Phagocytic cells (e.g., monocytes, macrophages and DCs) mediate some of these changes, when activated by pathogens, which often initiate the synthesis of proinflammatory cytokines [28]. The cytokine environment then influences the subsequent specific immune responses. This study provides strong evidence that MBL at higher concentrations $(10-20 \mu \mathrm{g} / \mathrm{ml})$, but not at lower concentrations $(1 \mu \mathrm{g} / \mathrm{ml})$, significantly inhibits LPS-induced TNF- $\alpha$ and IL-12 p40+p70 production, indicating that could affect the adaptive immune response by modulating the cytokine network.

It is known that mouse MBL-A interacts with the rough but not the smooth LPS [29]. Estabrook et al. [30] and Sprong et al. [31] also proved that human MBL did not interact with LPS. In the present study, smooth LPS was used to avoid interference from any LPS-MBL interaction. We also demonstrated that MBL itself did not bind to the smooth LPS used in this study. This evidence strongly supports the view that the MBLimMDC interaction rather than the MBL-LPS interaction affects LPS-induced cellular responses.

The functional MBL receptor expressed by many cell types is still controversial. As a major soluble PRR in the innate immune system, MBL has long been known to recognize pathogens or autologous apoptotic cells via its CRD and to interact with autologous cells via its CLR. It was believed that the CRD does not interact with normal autologous cells, but recently Downing et al. [32] reported calcium-dependent MBL binding to autogeneic B lymphocytes, monocytes and imMDCs via its C-type lectin-binding site, suggesting a new role of $\mathrm{MBL}$ in the immune system. In this study, there was clear evidence to demonstrate that MBL binds imMDCs at physiological calcium concentrations, though the binding was optimal at supraphysiological concentrations. SP-A directly interacts with TLR4 and MD-2 and regulates inflammatory cellular responses [33], and $\mathrm{MBL}$ and lung collectins interact with TLR4 and MD-2 by different mechanisms [34]. As LPS/TLR- signaling pathways are crucial for controlling the early inflammatory response and TLR4 is critical for LPS recognition and signaling [35], we presumed that TLR4 might be directly involved in MBL binding to the cell surface. It is also well known that LPS recognition is a complex process involving cooperation of several molecules such as LBP, CD14 and MD2, which enhance TLR4 signaling. Rat MBL might interact with CD14 [29]. Therefore, other cell surface molecules might play a role through binding to MBL. However, the molecular mechanisms by which MBL interacts with cells need to be investigated further.

LPS-activated cells sometimes induce microcirculatory dysfunction as well as inflammatory changes, which cause injury to various tissues, circulatory failure, and occasionally death [36-38]. To prevent excessive and prolonged responses by host innate immune cells to LPS, the host may acquire a down-regulating system, LPS tolerance, which ensures safe responses to LPS and/ or unresponsiveness to a second stimulation [39]. The fact that MBL at higher concentrations inhibits LPSinduced DC maturation and proinflammatory cytokine secretion suggests that it could provide such down-regulation in an inflammatory situation. In addition, the MBL preparation used in this study was determined without endotoxin by the Limulus amebocyte lysate assay, ruling out LPS tolerance induced by endotoxin contamination in the MBL preparations.

The serum concentration of $\mathrm{MBL}$ normally ranges from 0.01 to $10 \mu \mathrm{g} / \mathrm{ml}$ [40-42], but as an acute-phase protein, this can increase from 1.5 - to 3 -fold in patients during an acute phase response [43]. The serum levels of MBL in patients with rheumatic heart disease increased significantly up to $14 \mu \mathrm{g} / \mathrm{ml}$ [44]. MBL is also present in such extravascular milieux as synovial fluid, amniotic fluid, lung and vaginal lavages [45-49], and behaves as an acute-phase reactant in individuals with 'sufficient' (wild-type) MBL genotypes [50]. Therefore, we presume that MBL binding to autologous cells is most likely to take place at inflammatory loci, where local elevation of the extravascular MBL concentration and a concomitant influx of immune system cells are to be expected. The data presented in this paper showed that LPS-induced MDC functions were significantly modulated by MBL at higher concentrations $(10-20 \mu \mathrm{g} / \mathrm{ml})$ but not at lower concentrations $(1 \mu \mathrm{g} / \mathrm{ml})$. Therefore, by analogy, we presume that further investigations could provide evidence that, in the acute phase, high-concentration MBL is secreted to affect cytokine-mediated immune regulation in the serum as well as locally in some extravascular tissues. 
Therefore, these results suggest that MBL might have anti-inflammatory effects in pathological states. As a common exogenous pathogenic factor, LPS is not only a major mediator in the systemic inflammatory response and sepsis, but also a strong activator of monocytes, macrophages and DCs. During inflammatory shock, LPS stimulates monocytes to produce excessive inflammatory mediators and their cascade reactions, leading to multiple organ failure. Numerous studies have confirmed that the imbalanced cytokines mediating the interaction of natural and acquired immunity contribute to human sepsis and immune dysfunctions. Overproduction of proinflammatory cytokines (e.g. TNF- $\alpha$, IL-12, IFN- $\gamma$ and IL-18) results in sustained sepsis, shock, and even death $[51,52]$. In this study, higher concentrations of MBL inhibited LPS-induced DC maturation and the secretion of such proinflammatory cytokines as TNF- $\alpha$ and IL-12, indicating that MBL might be implicated in the anti-inflammatory effect and immunoregulation, reducing the incidence of shock and prevent endotoxemia-induced death. This study paves the way for a novel treatment of inflammatory shock by modulating excessive activated DCs with MBL.

\section{Conclusions}

In summary, we demonstrated in this study that MBL could attenuate MDCs maturation and cytokine production induced by LPS. MBL also bound directly to imMDCs and attenuated the binding of LPS to the cell surfaces, resulting in decreased LPS-induced nuclear NF- $\kappa$ B activity in these cells. All these data suggest that MBL could affect the functions of DCs by modifying LPS-induced cellular responses. This study supports an important role for $\mathrm{MBL}$ in the regulation of adaptive immune responses and inflammatory responses.

\section{Methods}

\section{Preparation of MBL}

MBL was isolated from human plasma according to Tan et al. [53], modified as described [54]. Briefly, a pool of freshly frozen human plasma (2.5 liters) (provided by Guangzhou General Hospital of Guangzhou Military Area Command of Chinese PLA, China) was thawed from $-80^{\circ} \mathrm{C}$ and, after extraction and elimination of most of the unrelated proteins, the residual fraction was solubilized and MBL was purified by a process involving three chromatographic steps. The first step was affinity chromatography on a mannan-agarose (Sigma, Poole, UK) column, which selected for functionally active, carbohydrate-binding MBL with about 2000-fold purification. The subsequent steps were anion-exchange chromatography and gel filtration on a Mono-Q HR 5/5 column (Pharmacia Biotech Europe, Orsay, France) and a Superose 6 HR 10/30 column (Pharmacia Biotech,
Orsay, France), respectively. The purified MBL was evaluated by SDS-PAGE and western blotting.

The MBL preparation was determined without endotoxin contamination by the Limulus amebocyte lysate assay. Biotinylated MBL was prepared by coupling Nhydroxysuccinimidobiotin to the purified MBL as described [55].

\section{Preparation of human DCs}

DCs were prepared from peripheral blood monocytes of healthy individuals. Briefly, peripheral blood mononuclear cells (PBMCs) were isolated by standard density gradient centrifugation and further separated on multistep Percoll gradients (Pharmacia, Uppsala, Sweden). The cells were suspended in IMDM (Gibco BRL, Gaithersburg, MD, USA) and allowed to adhere to 6-well tissue culture plates (Corning-Costar, MA, USA). After incubation for $40 \mathrm{~min}$ at $37^{\circ} \mathrm{C}$, non-adherent lymphocytes were removed. Adherent monocytes were harvested and washed twice, then cultivated for 5 days in IMDM containing rHuGM-CSF (115 ng/ml; Peprotech, Inc., Rocky Hill, N.J.) and rHuIL-4 (50 ng/ml; Peprotech, Inc.) and supplemented with $10 \%(\mathrm{v} / \mathrm{v})$ heat-inactivated fetal calf serum (FCS, Gibco BRL, Grand Island, CA), penicillin $(100 \mathrm{U} / \mathrm{ml})$ and streptomycin $(100 \mu \mathrm{g} / \mathrm{ml})$. The cells were kept in culture at a density of $10^{6}$ cells $/ \mathrm{ml}$ in 12 -well plates (Corning-Costar, MA, USA) at $37^{\circ} \mathrm{C}$ in a $5 \%(\mathrm{v} / \mathrm{v})$ $\mathrm{CO}_{2}$ atmosphere. On day 3, additional rHuGM-CSF (115 $\mathrm{ng} / \mathrm{ml})$ and $\mathrm{rHuIL}-4(50 \mathrm{ng} / \mathrm{ml})$ were added to the cultures. On day 5 , imMDCs were harvested by centrifugation at $450 \times \mathrm{g}$ for $5 \mathrm{~min}$ and washed with IMDM before the experiments.

To study the effect of MBL on maturation and cytokine production, the harvested imMDCs $\left(1 \times 10^{6}\right.$ cells/ $\mathrm{ml}$ ) were seeded in 12-well plates in complete IMDM, and maintained at $37^{\circ} \mathrm{C}$ in a $5 \%(\mathrm{v} / \mathrm{v}) \mathrm{CO}_{2}$ environment for $2 \mathrm{~h}$ after $\mathrm{MBL}$ was added to a range of final concentrations $(0-20 \mu \mathrm{g} / \mathrm{ml})$. rHuGM-CSF $(115 \mathrm{ng} / \mathrm{ml})$ and rHuIL-4 (50 ng/ml), and smooth LPS (100 ng/ml; from E. coli O111: B4, Campbell, CA), were added to the complete medium. Samples were kept at $37^{\circ} \mathrm{C}$ under a humidified $5 \% \mathrm{CO}_{2}$ environment for 2 days, and then analyzed. In control groups, human serum albumin (HSA, $20 \mu \mathrm{g} / \mathrm{ml}$ ) was used. To demonstrate the specificity of the responses to MBL, anti-MBL pAb (R\&D systems, MN, USA) was used.

\section{Flow cytometric determination of MDC phenotypes}

To determine phenotypes, MDCs were washed and then incubated in PBS containing $2 \%$ FCS and $0.01 \% \mathrm{NaN}_{3}$, with the following monoclonal antibodies (mAbs): FITC-conjugated anti-human HLA-DR and FITC-conjugated anti-human CD14 (Becton Dickinson, San Jose, USA), PE-conjugated anti-human CD1a, PE-conjugated 
anti-human CD86, PE-conjugated anti-human CD80, PE-conjugated anti-human CD83, FITC-conjugated antimouse IgG, and control mouse IgG (eBioscience, San Diego, USA). In control samples, the mAbs were substituted with matched isotype control mouse Ig (Becton Dickinson, San Jose, USA). Cells were analyzed in a FACScan equipped with Cell Quest software (Becton Dickinson, Mountain View, USA).

\section{Cytokine measurements}

The supernatants of the various samples were collected and stored at $-80^{\circ} \mathrm{C}$ pending analysis. For negative controls, the cells were cultured in complete medium only. Production of IL-12 p40+p70 and TNF- $\alpha$ were determined using ELISA kits (Bender MedSystems, San Diego, USA), as suggested by the manufacturers.

\section{Mixed lymphocyte reaction (MLR)}

$\mathrm{CD}^{+} \mathrm{T}$ cells were isolated from PBMCs as described [56]. Isolated $\mathrm{T}$ cells were transferred to 96-well flatbottom microplates (Corning-Costar, MA, USA) at a density of $2 \times 10^{5}$ cells/well. These T cells were cocultured with LPS-induced DCs preincubated with 15 $\mu \mathrm{g} / \mathrm{ml} \mathrm{MBL}$ in the indicated DC:T cell ratios, without additional exogenous cytokine. To demonstrate the specificity of responses to MBL, anti-MBL pAb was used. Proliferation of $\mathrm{T}$ cells was determined by ${ }^{3} \mathrm{H}$ thymidine (Perkin-Elmer, MA, USA) incorporation. Net counts per minute $(\mathrm{cpm})$ were measured in triplicate cultures.

\section{Effect of MBL on the binding of LPS to imMDCs}

ImMDCs were collected, and $10^{6}$ cells/tube were preincubated in the absence or presence of $10 \mu \mathrm{g} / \mathrm{ml} \mathrm{MBL}$ at $37^{\circ} \mathrm{C}$ for $30 \mathrm{~min}$. The cells were then further incubated with $100 \mathrm{ng} / \mathrm{ml}$ Alexa488-labeled smooth LPS (E. coli O111: B4, the molecular mass is $10,000 \mathrm{Da}$, Molecular Probes, MN, USA) at $4^{\circ} \mathrm{C}$ for $30 \mathrm{~min}$. After washing, the cells were analyzed by FACScan. To demonstrate the specificity of the response to MBL, anti-MBL pAb was added to MBL preparations for $10 \mathrm{~min}$ before incubating with the cells.

\section{Binding of MBL to imMDCs}

The ligand binding assay was performed as described [57]. Washed imMDCs $\left(2 \times 10^{5}\right)$ were resuspended in Tris-buffered saline (pH7.4) containing $5 \mathrm{mM} \mathrm{CaCl}_{2}, 1 \%$ bovine serum albumin (buffer A). Three kinds of Trisbuffered saline containing different calcium concentrations were alternatively used for binding assays. In the $\mathrm{Ca}^{2+}$-free control, $5 \mathrm{mM}$ EDTA was substituted for $\mathrm{CaCl}_{2}$. Each cell suspension $(0.2 \mathrm{ml})$ was first incubated for $30 \mathrm{~min}$ on ice with either biotinylated MBL or unlabelled MBL. The cells were incubated further for 30 min on ice with ExtrAvidin-FITC (Sigma, Madrid, Spain) at a final dilution of 1 in 100. After washing, the cells were analyzed by FACSCalibur.

The possibility that MBL itself binds to the LPS used in the experiments was also examined using microtiter wells. Smooth LPS (E. coli O111: B4), rough LPS [E. coli O111: B4 mutant (J5)] or mannan $(10 \mu \mathrm{g} / \mathrm{ml}$, $50 \mu \mathrm{l} /$ well; Sigma, St. Louis, USA) was coated on to the wells, which were incubated with $10 \mathrm{mM}$ Hepes buffer ( $\mathrm{pH} 7.4$ ) containing $0.15 \mathrm{M} \mathrm{NaCl}, 5 \mathrm{mM} \mathrm{CaCl}_{2}$, and $5 \%(\mathrm{w} / \mathrm{v})$ BSA (buffer $\mathrm{B})$ to block nonspecific binding. The indicated concentrations of MBL in buffer $B$ were added and incubated at $37^{\circ} \mathrm{C}$ for $1 \mathrm{~h}$. After washing, the wells were incubated with anti-human MBL mAb (1:5000). Binding was detected with HRP-labeled goat anti-mouse IgG, and the absorbance at $450 \mathrm{~nm}$ was measured.

\section{Analyses of NF-kB by EMSA and western blotting}

ImMDCs $\left(5 \times 10^{5}\right.$ cells/sample $)$ were stimulated with LPS $(100 \mathrm{ng} / \mathrm{ml})$ in the presence of $15 \mu \mathrm{g} / \mathrm{ml} \mathrm{MBL}$, $\mathrm{HAS}$, or MBL and anti-MBL pAb for $1 \mathrm{~h}$. The DCs were harvested and nuclear extracts were prepared using the NucBuster protein extraction kit (Novagen, Darmstadt, Germany). Oligonucleotide probes were radiolabeled with $\left[\gamma-{ }^{32} \mathrm{P}\right]$ ATP by $\mathrm{T} 4$ polynucleotide kinase (Takara, Tokyo, Japan). For the binding reaction, $5 \mu \mathrm{g}$ of nuclear extracts were incubated in $30 \mu \mathrm{l}$ total reaction buffer containing $10 \mathrm{mM}$ Hepes ( $\mathrm{pH}$ 7.9), $12.5 \%$ glycerol, $70 \mathrm{mM} \mathrm{NaCl}, 1 \mathrm{mM}$ DTT, $1 \mathrm{mM}$ EDTA, and $2 \mu \mathrm{g}$ poly(dI:dC). The ${ }^{32} \mathrm{P}$-labeled oligonucleotide was added to the reaction mixture and incubated for $20 \mathrm{~min}$ at room temperature. Samples were electrophoresed on 6\% acrylamide gels (made with 50 $\mathrm{mM}$ Tris buffer containing $380 \mathrm{mM}$ glycine and $2 \mathrm{mM}$ EDTA), followed by autoradiography.

For western blotting, the extracts were separated by $10 \%$ SDS-PAGE, followed by transfer to a nitrocellulose membrane (BioRad, CA, USA). After blocking with $5 \%$ fat-free milk protein in triethanolaminebuffered saline (TBS), pH 7.5, the membrane was incubated with the NF- $\kappa$ B-specific mouse anti-human mAb p65 (Santa Cruz Biotechnology, CA, USA). After washing, HRP-conjugated secondary antibody was added to the membrane in TBS containing $0.1 \%$ Tween 20. As an internal control, actin was used. An enhanced chemiluminescence detection system (ECL, Amersham Biosciences, Sweden) was used to visualize the protein bands.

\section{Statistical analysis}

The mean and SD were calculated by Excel software (Microsoft). Student's t-test was used for statistical analysis, and $P<0.05$ was considered significant. 


\section{Additional material}

Additional file 1: Fig. S1: MBL does not bind to smooth LPS.

Microtiter wells were coated with smooth LPS, rough LPS or mannan (10 $\mu \mathrm{g} / \mathrm{ml}, 50 \mu \mathrm{l} / \mathrm{well}$ ), and incubated with $\mathrm{MBL}$ at $37^{\circ} \mathrm{C}$ for $1 \mathrm{~h}$. The binding of MBL was detected using anti-MBL MAb and HRP-labeled goat antimouse lgG as described under "Methods". The data shown are means \pm S.E. of three experiments.

\section{Abbreviations}

MBL: mannan-binding lectin; APC: antigen presenting cell; CLR: collagen-like region; CRD: carbohydrate-recognition; domain; DC: dendritic cell; EMSA: electrophoretic mobility shift assay; HRP: horseradish peroxidase; HSA human serum albumin; LPS: lipopolysaccharide; mAb: monoclonal antibody; MDC: monocyte-derived dendritic cell; pAb: polyclonal antibody; PRR: pattern recognition receptor; SP-A: surfactant proteins A; SP-D: surfactant proteins D; sTLR4: soluble form of recombinant extracellular domain of TLR4; TLR4: Toll-like receptor 4; TNF: tumor necrosis factor.

\section{Acknowledgements}

Very special thanks should be given to Dr. Steve Hedrick for contributive discussion. We would like to thank professors Ping Liang, Jian-Wu Song and Wei-Ren Dong for their dedicated revision of the paper. Funding

This work was supported by Natural Science Foundation of China (30972679).

\section{Author details}

'Department of Immunology, Southern Medical University, Guangzhou, 510515, PR China. ${ }^{2}$ Department of Medical Tests, Xinxiang Medical University, Xinxiang, 453003, PR China.

\section{Authors' contributions}

WMY participated in the study design, carried out the cytokine measurements, contributed to the analysis of NF- $\kappa$ B activity, performed the statistical analyses for all studies and drafted the manuscript. CY participated in the study design and the analysis of cytokine expression. ZYN contributed to the analysis of DC maturation. ZLY prepared the MBL and contributed to the cultivation of cells. $\mathbf{L X}$ operated the flow cytometer in all the experiments and contributed to flow cytometric analysis. CZL designed the study, interpreted the data and drafted the manuscript. All authors read and approved the final manuscript.

Received: 30 September 2010 Accepted: 1 January 2011 Published: 1 January 2011

\section{References}

1. Lu J, Wiedemann H, Timpl R, Reid KB: Similarity in structure between C1q and the collectins as judged by electron microscopy. Behring Inst Mitt 1993, 6-16.

2. Palaniyar N, Zhang L, Kuzmenko A, Ikegami M, Wan S, Wu H, Korfhagen TR, Whitsett JA, McCormack FX: The role of pulmonary collectin N-terminal domains in surfactant structure, function, and homeostasis in vivo. $J$ Biol Chem 2002, 277:26971-9.

3. Schweinle JE, Nishiyasu M, Ding TQ, Sastry K, Gillies SD, Ezekowitz RA: Truncated forms of mannose-binding protein multimerize and bind to mannose-rich Salmonella montevideo but fail to activate complement in vitro. J Biol Chem 1993, 268:364-70

4. Ikegami M, Elhalwagi BM, Palaniyar N, Dienger K, Korfhagen T, Whitsett JA, McCormack FX: The collagen-like region of surfactant protein A (SP-A) is required for correction of surfactant structural and functional defects in the SP-A null mouse. J Biol Chem 2001, 276:38542-8.

5. Sheriff $S$, Chang CY, Ezekowitz RA: Human mannose-binding protein carbohydrate recognition domain trimerizes through a triple alphahelical coiled-coil. Nat Struct Biol 1994, 1:789-94.

6. Hakansson K, Lim NK, Hoppe HJ, Reid KB: Crystal structure of the trimeric alpha-helical coiled-coil and the three lectin domains of human lung surfactant protein D. Structure 1999, 7:255-64.
7. Weis WI, Kahn R, Fourme R, Drickamer K, Hendrickson WA: Structure of the calcium-dependent lectin domain from a rat mannose-binding protein determined by MAD phasing. Science 1991, 254:1608-15.

8. Palaniyar N, lkegami M, Korfhagen T, Whitsett J, McCormack FX: Domains of surfactant protein $\mathrm{A}$ that affect protein oligomerization, lipid structure and surface tension. Comp Biochem Physiol A Mol Integr Physiol 2001, 129:109-27.

9. Banchereau J, Steinman RM: Dendritic cells and the control of immunity. Nature 1998, 392:245-52.

10. Sallusto F, Cella M, Danieli C, Lanzavecchia A: Dendritic cells use macropinocytosis and the mannose receptor to concentrate macromolecules in the major histocompatibility complex class II compartment: downregulation by cytokines and bacterial products. J Exp Med 1995, 182:389-400.

11. Svensson M, Stockinger B, Wick MJ: Bone marrow-derived dendritic cells can process bacteria for MHC-I and MHC-II presentation to T cells. J Immunol 1997, 158:4229-36.

12. Banchereau J, Briere F, Caux C, Davoust J, Lebecque S, Liu YJ, Pulendran B, Palucka K: Immunobiology of dendritic cells. Annu Rev Immunol 2000, 18:767-811.

13. Brinker KG, Garner H, Wright JR: Surfactant protein A modulates the differentiation of murine bone marrow-derived dendritic cells. Am J Physiol Lung Cell Mol Physiol 2003, 284:L232-41.

14. Stamme C, Muller M, Hamann L, Gutsmann T, Seydel U: Surfactant protein a inhibits lipopolysaccharide-induced immune cell activation by preventing the interaction of lipopolysaccharide with lipopolysaccharide-binding protein. Am J Respir Cell Mol Biol 2002, 27:353-60

15. McIntosh JC, Mervin-Blake S, Conner E, Wright JR: Surfactant protein A protects growing cells and reduces TNF-alpha activity from LPSstimulated macrophages. Am J Physiol 1996, 271:L310-9.

16. Borron P, McIntosh JC, Korfhagen TR, Whitsett JA, Taylor J, Wright JR: Surfactant-associated protein A inhibits LPS-induced cytokine and nitric oxide production in vivo. Am J Physiol Lung Cell Mol Physiol 2000, 278: L840-7.

17. Brinker KG, Martin E, Borron P, Mostaghel E, Doyle C, Harding CV, Wright JR: Surfactant protein $D$ enhances bacterial antigen presentation by bone marrow-derived dendritic cells. Am J Physiol Lung Cell Mol Physiol 2001, 281:L1453-63

18. Yamada M, Oritani K, Kaisho T, Ishikawa J, Yoshida H, Takahashi I, Kawamoto S, Ishida N, Ujiie H, Masaie $\mathrm{H}$, et al: Complement C1q regulates LPS-induced cytokine production in bone marrow-derived dendritic cells. Eur J Immunol 2004, 34:221-30.

19. Csomor E, Bajtay Z, Sandor N, Kristof K, Arlaud GJ, Thiel S, Erdei A: Complement protein $\mathrm{C} 1 \mathrm{q}$ induces maturation of human dendritic cells. Mol Immunol 2007, 44:3389-97.

20. Chaka W, Verheul AF, Vaishnav W, Cherniak R, Scharringa J, Verhoef J, Snippe H, Hoepelman Al: Induction of TNF-alpha in human peripheral blood mononuclear cells by the mannoprotein of Cryptococcus neoformans involves human mannose binding protein. J Immunol 1997, 159:2979-85.

21. Soell M, Diab M, Haan-Archipoff G, Beretz A, Herbelin C, Poutrel B, Klein JP: Capsular polysaccharide types 5 and 8 of Staphylococcus aureus bind specifically to human epithelial (KB) cells, endothelial cells, and monocytes and induce release of cytokines. Infect Immun 1995, 63:1380-6.

22. Ghezzi MC, Raponi G, Angeletti S, Mancini C: Serum-mediated enhancement of TNF-alpha release by human monocytes stimulated with the yeast form of Candida albicans. J Infect Dis 1998, 178:1743-9.

23. Takahashi K, Gordon J, Liu H, Sastry KN, Epstein JE, Motwani M, Laursen I, Thiel S, Jensenius JC, Carroll M, et al: Lack of mannose-binding lectin-A enhances survival in a mouse model of acute septic peritonitis. Microbes Infect 2002, 4:773-84.

24. Shortman K, Liu YJ: Mouse and human dendritic cell subtypes. Nat Rev Immunol 2002, 2:151-61.

25. Smits HH, de Jong EC, Wierenga EA, Kapsenberg ML: Different faces of regulatory DCs in homeostasis and immunity. Trends Immunol 2005, 26:123-9.

26. Macdonald SL, Downing I, Atkinson AP, Gallagher RC, Turner ML, Kilpatrick DC: Dendritic cells previously exposed to mannan-binding lectin enhance cytokine production in allogeneic mononuclear cell cultures. Hum Immunol 2010, 71:1077-83. 
27. Hoebe K, Janssen E, Beutler B: The interface between innate and adaptive immunity. Nat Immunol 2004, 5:971-4

28. Underhill DM, Ozinsky A: Phagocytosis of microbes: complexity in action. Annu Rev Immunol 2002, 20:825-52.

29. Chiba H, Sano H, Iwaki D, Murakami S, Mitsuzawa H, Takahashi T, Konishi M, Takahashi H, Kuroki Y: Rat mannose-binding protein a binds CD14. Infect Immun 2001, 69:1587-92

30. Estabrook MM, Jack DL, Klein NJ, Jarvis GA: Mannose-binding lectin binds to two major outer membrane proteins, opacity protein and porin, of Neisseria meningitidis. J Immunol 2004, 172:3784-92

31. Sprong $T$, Jack $D L$, Klein NJ, Turner MW, van der Ley $P$, Steeghs $L$, Jacobs $L$, van der Meer JW, van Deuren M: Mannose binding lectin enhances IL1 beta and IL-10 induction by non-lipopolysaccharide (LPS) components of Neisseria meningitidis. Cytokine 2004, 28:59-66.

32. Downing I, MacDonald SL, Turner ML, Kilpatrick DC: Detection of an autologous ligand for mannan-binding lectin on human B lymphocytes. Scand J Immunol 2005, 62:507-14.

33. Yamada C, Sano H, Shimizu T, Mitsuzawa H, Nishitani C, Himi T, Kuroki Y: Surfactant protein A directly interacts with TLR4 and MD-2 and regulates inflammatory cellular response. Importance of supratrimeric oligomerization. J Biol Chem 2006, 281:21771-80.

34. Shimizu T, Nishitani C, Mitsuzawa H, Ariki S, Takahashi M, Ohtani K, Wakamiya N, Kuroki Y: Mannose binding lectin and lung collectins interact with Toll-like receptor 4 and MD-2 by different mechanisms. Biochim Biophys Acta 2009, 1790:1705-10.

35. Chow JC, Young DW, Golenbock DT, Christ WJ, Gusovsky F: Toll-like receptor-4 mediates lipopolysaccharide-induced signal transduction. J Biol Chem 1999, 274:10689-92.

36. Freudenberg MA, Keppler D, Galanos C: Requirement for lipopolysaccharide-responsive macrophages in galactosamine-induced sensitization to endotoxin. Infect Immun 1986, 51:891-5.

37. Michalek SM, Moore RN, McGhee JR, Rosenstreich DL, Mergenhagen SE: The primary role of lymphoreticular cells in the mediation of host responses to bacterial endotoxim. J Infect Dis 1980, 141:55-63.

38. Ulevitch RJ, Tobias PS: Receptor-dependent mechanisms of cell stimulation by bacterial endotoxin. Annu Rev Immunol 1995, 13:437-57.

39. Ziegler-Heitbrock HW, Wedel A, Schraut W, Strobel M, Wendelgass P, Sternsdorf T, Bauerle PA, Haas JG, Riethmuller G: Tolerance to lipopolysaccharide involves mobilization of nuclear factor kappa B with predominance of p50 homodimers. J Biol Chem 1994, 269:17001-4.

40. Turner MW, Hamvas RM: Mannose-binding lectin: structure, function, genetics and disease associations. Rev Immunogenet 2000, 2:305-22.

41. Bohlson SS, Fraser DA, Tenner AJ: Complement proteins C1q and MBL are pattern recognition molecules that signal immediate and long-term protective immune functions. Mol Immunol 2007, 44:33-43.

42. Thiel S: Complement activating soluble pattern recognition molecules with collagen-like regions, mannan-binding lectin, ficolins and associated proteins. Mol Immunol 2007, 44:3875-88.

43. Petersen SV, Thiel S, Jensenius JC: The mannan-binding lectin pathway of complement activation: biology and disease association. Mol Immunol 2001, 38:133-49.

44. Schafranski MD, Stier A, Nisihara R, Messias-Reason IJ: Significantly increased levels of mannose-binding lectin (MBL) in rheumatic heart disease: a beneficial role for MBL deficiency. Clin Exp Immunol 2004, 138:521-5

45. Malhotra R, Wormald MR, Rudd PM, Fischer PB, Dwek RA, Sim RB: Glycosylation changes of IgG associated with rheumatoid arthritis can activate complement via the mannose-binding protein. Nat Med 1995, 1:237-43.

46. Malhotra R, Willis AC, Lopez Bernal A, Thiel S, Sim RB: Mannan-binding protein levels in human amniotic fluid during gestation and its interaction with collectin receptor from amnion cells. Immunology 1994 82:439-44

47. Gomi K, Tokue Y, Kobayashi T, Takahashi H, Watanabe A, Fujita T, Nukiwa T: Mannose-binding lectin gene polymorphism is a modulating factor in repeated respiratory infections. Chest 2004, 126:95-9.

48. Babula O, Lazdane G, Kroica J, Ledger WJ, Witkin SS: Relation between recurrent vulvovaginal candidiasis, vaginal concentrations of mannosebinding lectin, and a mannose-binding lectin gene polymorphism in Latvian women. Clin Infect Dis 2003, 37:733-7.
49. Pellis V, De Seta F, Crovella S, Bossi F, Bulla R, Guaschino S, Radillo O, Garred P, Tedesco F: Mannose binding lectin and C3 act as recognition molecules for infectious agents in the vagina. Clin Exp Immunol 2005, 139:120-6.

50. Thiel S, Holmskov U, Hviid L, Laursen SB, Jensenius JC: The concentration of the C-type lectin, mannan-binding protein, in human plasma increases during an acute phase response. Clin Exp Immunol 1992 90:31-5

51. Vallespi MG, Alvarez-Obregon JC, Rodriguez-Alonso I, Montero T, Garay H, Reyes O, Arana MJ: A Limulus anti-LPS factor-derived peptide modulates cytokine gene expression and promotes resolution of bacterial acute infection in mice. Int Immunopharmacol 2003, 3:247-56.

52. Ono S, Ueno C, Seki S, Matsumoto A, Mochizuki H: Interleukin-12 and -18 induce severe liver injury in mice recovered from peritonitis after sublethal endotoxin challenge. Surgery 2003, 134:92-100.

53. Tan SM, Chung MC, Kon OL, Thiel S, Lee SH, Lu J: Improvements on the purification of mannan-binding lectin and demonstration of its $\mathrm{Ca}(2$ +)-independent association with a C1s-like serine protease. Biochem J 1996, 319(Pt 2):329-32

54. Dumestre-Perard C, Ponard D, Arlaud GJ, Monnier N, Sim RB, Colomb MG: Evaluation and clinical interest of mannan binding lectin function in human plasma. Mol Immunol 2002, 39:465-73.

55. Kilpatrick DC, Fujita T, Matsushita M: P35, an opsonic lectin of the ficolin family, in human blood from neonates, normal adults, and recurrent miscarriage patients. Immunol Lett 1999, 67:109-12.

56. Sato K, Kawasaki H, Nagayama H, Enomoto M, Morimoto C, Tadokoro K, Juji T, Takahashi T: Chemokine receptor expressions and responsiveness of cord blood T cells. J Immunol 2001, 166:1659-66.

57. Bajtay Z, Jozsi M, Banki Z, Thiel S, Thielens N, Erdei A: Mannan-binding lectin and $\mathrm{C} 1 \mathrm{q}$ bind to distinct structures and exert differential effects on macrophages. Eur J Immunol 2000, 30:1706-13.

doi:10.1186/1471-2172-12-1

Cite this article as: Wang et al:: Mannan-binding lectin regulates dendritic cell maturation and cytokine production induced by lipopolysaccharide. BMC Immunology 2011 12:1.

\section{Submit your next manuscript to BioMed Central and take full advantage of:}

- Convenient online submission

- Thorough peer review

- No space constraints or color figure charges

- Immediate publication on acceptance

- Inclusion in PubMed, CAS, Scopus and Google Scholar

- Research which is freely available for redistribution

Submit your manuscript at www.biomedcentral.com/submit
C) Biomed Central 